\title{
A Design-Around Solution for a MMX-Based Tablet Drug Comprising Mesalazine- A Lesson from Shire Development, LLC v. Watson Pharmaceuticals, Inc.
}

\author{
By PING-HSUN CHEN
}

\begin{abstract}
This article explores Shire Development, LLC v. Watson Pharmaceuticals, Inc., 848 F.3d 981 (Fed. Cir. 2017) and illustrates some implications for designing around a MMX-based tablet drug, Lialda. The MMX technology is known for its lipophilic matrix and hydrophilic matrix in a tablet, while the former matrix is dispersed within the latter one. In Shire Development, $L L C$, the disputed claim recited a Markush limitation for the hydrophilic matrix and excludes unlisted materials from the hydrophilic matrix. On the other hand, the accused generic drug included magnesium stearate, a lipophilic material, in its hydrophilic matrix and, therefore, did not infringe the disputed patent. The case opens a door for generic drug companies to design around the patented MMX technology underlying Lialda.
\end{abstract}

\section{INTRODUCTION}

$\mathrm{T}$ he Multi-Matrix System (MMX) TechnolOGY was developed by Cosmo Pharmaceuticals SpA, Milan, originally for making Lialda, an oral formulation of mesalazine (a.k.a. mesalamine or 5-amino-salicylic acid) for treating ulcerative colitis (UC), a chronic inflammatory disease of the colon and rectum. ${ }^{1}$ The technology provides a tablet that contains lipophilic excipients and hydrophilic excipients to form a core that is enclosed within a gastro-resistant, pH-dependent coating. ${ }^{2}$ The core is a polymeric matrix in a form of a double matrix where a lipophilic matrix is dispersed within a hydrophilic matrix. ${ }^{3}$ Mesalazine,

Keywords: Multi-Matrix System, 5-amino-salicylic acid, Lialda, design around, new abbreviated drug application

Ping-Hsun Chen is Associate Professor at the Graduate Institute of Technology, Innovation, and Intellectual Property Management at National Chengchi University in Taipei, Taiwan. Mr. Chen holds a JD ('10) and LLM ('08) from Washington University in St. Louis School of Law; an LLM ('07) from National Chengchi University in Taiwan; and a BS ('97) and MS ('99) in Chem. Eng. from National Taiwan University in Taiwan. E-mail for Mr. Chen: cstr@nccu.edu.tw the active ingredient of Lialda, is incorporated primarily in microparticles of the lipophilic matrix. ${ }^{4}$

\footnotetext{
${ }^{1}$ See Joaquín Hinojosa, Víctor Navas, and Cristina Saro, Pharmacokinetics: Efficacy and Safety of MMX Mesalamine Formulation for Treating Ulcerative Colitis, 29 Revista Colombiana de Gastroenterologia 41, 4142 (2014), available at http://www.scielo.org.co/pdf/rcg/ v29n1/en_v29n1a07.pdf (last visited Aug. 29, 2019); see also Silvia Nardelli et al., MMX ${ }^{\circledR}$ Technology and its Applications in Gastrointestinal Diseases, 10 THERaPeutic Advances in Gastroenterology 545, 545-46 (2017), available at https://air.unimi.it/retrieve/handle/ 2434/521801/931194/MMXTechnology_2017.pdf (last visited Aug. 29, 2019); Press Release, GolinHarris International, FDA Approves LIALDA ${ }^{\mathrm{TM}}$ (Mesalamine) (Jan. 16, 2007), https://www.eurekalert.org/pub_releases/ 2007-01/gi-fal011607.php (last visited Aug. 30, 2019); Cosmo Pharmaceuticals S.P.A., AnNual Report 20083 (2009), available at https://www.cosmopharma.com/ /media/ Files/C/Cosmo-Pharmaceuticals-V2/financial-reports/ar08.pdf (last visited Aug. 31, 2019).

${ }^{2}$ See Nardelli et al., supra note 1, at 545; see also Cosimo Prantera et al., A New Oral Delivery System for 5-ASA: Preliminary Clinical Findings for MMx, 11 INFLAMMATORY Bowel Diseases 421, 421 (2005).

${ }^{3}$ See Prantera et al., supra note 2, at 421.

${ }^{4}$ See id.
} 
The drug release mechanism of a MMX tablet first relies on a gastro-resistant coating that helps the tablet remains intact in the stomach. ${ }^{5}$ The embedded active ingredient is not released until the tablet reaches an environment of a $\mathrm{pH}$ of seven or higher, which normally occurs in the terminal ileum. ${ }^{6}$ Then, the coating disintegrates in the terminal ileum. ${ }^{7}$ The hydrophilic matrix starts to erode and turns the tablet into a viscous gel mass. ${ }^{8}$ The lipophilic matrix functions to slow the penetration of aqueous fluids into the core. ${ }^{9}$ Meanwhile, the active ingredient begins to diffuse from the lipophilic matrix. ${ }^{10}$

Through the MMX mechanism, Lialda delivers mesalazine to the whole colonic mucosa through an almost linear kinetics profile. ${ }^{11}$ The exposure of the colonic mucosa to mesalazine is homogeneous and prolonged, such that the therapeutic amount of mesalazine can be reached at the targeted site. ${ }^{12}$

Lialda was approved by the U.S. Food and Drug Administration (FDA) on January $16,2007 .{ }^{13}$ Currently, Shire Development LLC (or Inc.) markets Lialda. ${ }^{14}$ The FDA's Approved Drug Products with Therapeutic Equivalence Evaluations (a.k.a. Orange Book) lists one patent, U.S. Patent No. 6,773,720 ('720 Patent), for Lialda. ${ }^{15}$ The ' 720 Patent is owned by Cosmo Technologies Ltd. and licensed exclusively to Nogra Pharma Ltd., which has granted an exclusive sublicense to Shire Pharmaceutical Development Inc. ${ }^{16}$

In 2012, Watson Laboratories, Inc., a subsidiary of Watson Pharmaceuticals, Inc., filed an Abbreviated New Drug Application (ANDA) for its generic version of Lialda with the FDA, ${ }^{17}$ and it also submitted a "Paragraph IV" certification under 21 U.S.C. $§ 355(\mathrm{j})(2)(\mathrm{A})(\mathrm{vii})(\mathrm{IV}){ }^{18}$ Consequently, a lawsuit under 35 U.S.C. § 271(e)(2)(A) was brought against Watson and its affiliates (together as Watson). ${ }^{19}$ Watson was alleged to infringe the '720 Patent. ${ }^{20}$

In 2013, the district court in Shire II found that Watson infringed claims 1 and 3 of the '720 Patent. ${ }^{21}$ In 2014, the Federal Circuit in Shire III remanded the case, because the district court incorrectly construed the disputed claim term. ${ }^{22}$ But, the Shire III decision was vacated and remanded by the Supreme Court in Shire IV, because the case law concerning claim construction had been changed. ${ }^{23}$ In 2015, the Federal Circuit in Shire $V$ found that the case did not involve factual findings and, therefore, upheld its previous decision. $^{24}$ Then, the case returned to the district court which in Shire VI still found that the '720 Patent had been infringed. ${ }^{25}$

Finally, the case reached the Federal Circuit again. ${ }^{26}$ In 2017, the Federal Circuit in Shire VII reversed the district court's decision and required the district court to issue judgment of noninfringement. ${ }^{27}$ The issue centered on whether the generic drug met claim 1's "outer hydrophilic matrix" limitation. ${ }^{28}$ The disputed limitation was a Markush limitation reciting "selected from the group consisting of" that limits the claim scope exactly to the

${ }^{5}$ See id.

${ }^{6}$ See Nardelli et al., supra note 1, at 545.

${ }^{7}$ See id.

${ }^{8}$ See Prantera et al., supra note 2, at 421; see also Nardelli et al., supra note 1, at 545 .

${ }^{9}$ See Nardelli et al., supra note 1 , at 545.

${ }^{10}$ See Prantera et al., supra note 2, at 421.

${ }^{11}$ See Prantera et al., supra note 2, at 421; see also Nardelli et al., supra note 1 , at 545 .

${ }^{12}$ See Nardelli et al., supra note 1, at 545.

${ }^{13}$ See U.S. Food and Drug Administration (FDA), Drug Approval Package-Lialda (Mesalamine) Delayed Release Tablets, https://www.accessdata.fda.gov/drugsatfda_docs/nda/ 2007/022000s000TOC.cfm (last visited Sept. 3, 2019).

${ }^{14}$ See Shire Dev., LLC, v. Mylan Pharm., Inc., 235 F. Supp. 3d 1298, 1302 (M.D. Fla. 2017).

${ }^{15}$ See FDA, Patent and Exclusivity for: N022000, ORANGE BooK, https://www.accessdata.fda.gov/scripts/cder/ob/pat ent_info.cfm?Product_No=001\&Appl_No=022000\&Appl_ type $=\mathrm{N}$ (last visited Sept. 3, 2019); see also Mylan Pharm., Inc., 235 F. Supp. 3d at 1302.

${ }^{16}$ See Mylan Pharm., Inc., 235 F. Supp. 3d at 1301.

${ }^{17}$ See Press Release, Watson Pharmaceuticals, Watson Confirms Lialda ${ }^{\circledR}$ Patent Challenge (May 9, 2012), https://www .prnewswire.com/news-releases/watson-confirms-lialda-patentchallenge-150831455.html (last visited Sept. 3, 2019).

${ }^{18}$ See Shire Dev. LLC v. Watson Pharm., Inc., No. 1260862-CIV, 2013 WL 1912208, at *1-*2 (S.D. Fla. May 9 , 2013) [hereinafter Shire II].

${ }^{19}$ See Shire II, 2013 WL 1912208, at $* 1$.

${ }^{20}$ See Shire II, 2013 WL 1912208, at *1; see also Shire Dev. LLC v. Watson Pharm., Inc., No. 12-60862-CIV, 2013 WL 174843, at *1 (S.D. Fla. Jan. 17, 2013) [hereinafter Shire I]. ${ }^{21}$ See Shire II, 2013 WL 1912208, at *16.

${ }^{22}$ See Shire Dev., LLC v. Watson Pharm., Inc., 746 F.3d 1326, 1334 (Fed. Cir. 2014) [hereinafter Shire III].

${ }^{23}$ See Shire Dev., LLC v. Watson Pharm., 135 S. Ct. 1174, 1174 (2015) (citing Teva Pharm. USA, Inc. v. Sandoz, Inc., 574 U.S. 318 (2015)) [hereinafter Shire IV]. Before Teva Pharm. USA, Inc., the Federal Circuit reviewed de novo district court's factual determination concerning claim construction. See id., 574 U.S. at 836. The Supreme Court clarified that the proper standard is the "clearly erroneous" standard. See id. at 838. For more information, please read William M. Jay, Changing the Claim-Construction Standard of Review, 44 AIPLA Q.J. 553 (2016).

${ }^{24}$ See Shire Dev., LLC v. Watson Pharm., Inc., 787 F.3d 1359, 1361 (Fed. Cir. 2015) [hereinafter Shire V].

${ }^{25}$ See Shire Dev. LLC v. Watson Pharm., Inc., No. 12-60862CIV, 2016 WL 1258885, at *15 -*16 (S.D. Fla. Mar. 28, 2016)

[hereinafter Shire VI].

${ }^{26}$ See Shire Dev., LLC v. Watson Pharm., Inc., 848 F.3d 981, 984 (Fed. Cir. 2017) [hereinafter Shire VII].

${ }^{27}$ See Shire VII, 848 F.3d at 986-87.

${ }^{28}$ See id. at 984 . 
selected elements, ${ }^{29}$ as opposed to the general law of literal infringement merely requiring a plaintiff to "show that the accused device contains each and every limitation of the asserted claims." ${ }^{30}$ Ultimately, the Federal Circuit found that the outer hydrophilic matrix of Watson's generic drug had an ingredient that is not one of the selected elements of the disputed limitation. ${ }^{31}$ Thus, the Federal Circuit held that the defendants did not infringe the '720 Patent. ${ }^{32}$

This article is intended to explore the Federal Circuit's decision in Shire VII and to explain a way of designing around the patented MMX technology. First, Part II introduces the background of the Shire VII decision and focuses on technical aspects of the patented pharmaceutical composition and Watson's generic drug and the district court's decision concerning the disputed Markush limitation. Part III discusses the Federal Circuit's noninfringement judgment. Finally, Part IV shares some implications drawn from Shire VII for purposes of designing around the MMX technology applied in Lialda.

\section{BACKGROUND OF SHIRE DEVELOPMENT, LLC V. WATSON PHARMACEUTICALS, INC.}

\section{A. Patented technology}

In Shire VII, the Federal Circuit characterized the patented controlled-release oral pharmaceutical composition as including "the mesalamine active ingredient; an inner, lipophilic matrix; an outer, hydrophilic matrix; and other optional excipients." 33 The Shire VII decision focused on claim 1 of the '720 Patent which recites:

1. Controlled-release oral pharmaceutical compositions containing as an active ingredient 5-amino-salicylic acid, comprising:

a) an inner lipophilic matrix consisting of substances selected from the group consisting of unsaturated and/or hydrogenated fatty acid, salts, esters or amides thereof, fatty acid mono-, di- or triglycerids, waxes, ceramides, and cholesterol derivatives with melting points below $90^{\circ} \mathrm{C}$., and wherein the active ingredient is dispersed both in said the lipophilic matrix and in the hydrophilic matrix;

b) an outer hydrophilic matrix wherein the lipophilic matrix is dispersed, and said outer hydrophilic matrix consists of com- pounds selected from the group consisting of polymers or copolymers of acrylic or methacrylic acid, alkylvinyl polymers, hydroxyalkyl celluloses, carboxyalkyl celluloses, polysaccharides, dextrins, pectins, starches and derivatives, alginic acid, and natural or synthetic gums;

c) optionally other excipients;

wherein the active ingredient is present in an amount of 80 to $95 \%$ by weight of the total composition, and wherein the active ingredient is dispersed both in the lipophilic matrix and in the hydrophilic matrix. ${ }^{34}$

Several claim terms were construed in Shire VII. ${ }^{35}$ First, according to the parties' stipulation, the Federal Circuit defined a "hydrophilic matrix" as having "an affinity for water and therefore readily dissolv[ing] in it" 36 and a "lipophilic matrix" as having "an affinity for lipids and therefore resist[ing] dissolving in water." ${ }^{37}$ In addition, following its 2015 decision, the Federal Circuit reinstated that two "matrices are "defined by mutually exclusive spatial characteristics - one inner, one outer - and mutually exclusive compositional characteristics-one

\footnotetext{
${ }^{29}$ See Shire VII, 848 F.3d at 984-85; see also Abbott Labs. v. Baxter Pharm. Prod., Inc., 334 F.3d 1274, 1280 (Fed. Cir. 2003) ("A Markush group is a listing of specified alternatives of a group in a patent claim, typically expressed in the form: a member selected from the group consisting of A, B, and C."); Abbott Labs. v. Andrx Pharm., Inc., 473 F.3d 1196, 1210 (Fed. Cir. 2007) ("A Markush group is a form of drafting a claim term that is approved by the PTO to serve a particular purpose when used in a claim-to limit the claim to a list of specified alternatives."); Vehicular Techs. Corp. v. Titan Wheel Int'l, Inc., 212 F.3d 1377, 1383 (Fed. Cir. 2000) ("In simple terms, a drafter uses the phrase 'consisting of' to mean 'I claim what follows and nothing else.' A drafter uses the term 'comprising' to mean 'I claim at least what follows and potentially more."').

${ }^{30}$ Shire VI, 2016 WL 1258885, at *5 (quoting Presidio Components, Inc. v. Am. Technical Ceramics Corp., 702 F.3d 1351, 1358 (Fed. Cir. 2012)).

${ }^{31}$ See Shire VII, 848 F.3d at $985-86$.

${ }^{32}$ See id. at $986-87$.

${ }^{33} I d$. at 983 (citing U.S. Patent No. 6,773,720 col.2 11.3644).

${ }^{34}$ U.S. Patent No. 6,773,720 claim 1; see also Shire V, 787 F.3d at 1362; Shire VII, 848 F.3d at 983.

${ }^{35}$ See Shire VII, 848 F.3d at $983-84$.

${ }^{36} I d$. at 983 (internal quotation marks omitted) (citing Shire V, 787 F.3d at 1362 n.1; Shire VI, 2016 WL 1258885, at *6).

${ }^{37} I d$. (internal quotation marks omitted) (citing Shire V, 787 F.3d at 1362 n.1, 1365).
} 
hydrophilic, one lipophilic." 38 Moreover, the Federal Circuit affirmed that claim 1 required "the inner volume contain substances from the group described for the inner lipophilic matrix (which are all lipophilic substances), and that the outer volume separately contain substances from the group described for the outer hydrophilic matrix (which are all hydrophilic)." 39

\section{B. Watson's generic drug}

Watson's generic drug was a controlled-release oral pharmaceutical composition in the form of a tablet coated with an enteric coating and a film coating. ${ }^{40}$ The active ingredient was 5-amino-salicylic acid in an amount of $80-95 \%$ by weight of the total composition. ${ }^{41}$ The generic drug contained two separate volumes: (1) granules and (2) extragranular space that is the space outside of the granules. $^{42}$ The active ingredient was dispersed in the granules, and it was also in a form of fines (small particles) dispersed in the extragranular space. ${ }^{43}$

The granule region was considered equivalent to the "inner lipophilic matrix" limitation and included magnesium stearate and other excipients (specifically, povidone, copovidone, and microcrystalline cellulose).$^{44}$ Magnesium stearate as a main component was responsible solely for the lipophilic characteristic of the granule region. ${ }^{45}$ Magnesium stearate was specifically magnesium stearate dihydrate with a melting point below $90^{\circ} \mathrm{C} .{ }^{46}$

On the other hand, the extragranular space was considered equivalent to the "outer hydrophilic matrix" limitation and composed mainly of sodium starch glycolate. ${ }^{47}$ The extragranular space also contained magnesium stearate and colloidal silicon dioxide. ${ }^{48}$ While the magnesium stearate retained its lipophilic property in the extragranular space, ${ }^{49}$ the extragranular space overall exhibited hydrophilic characteristics. ${ }^{50}$

\section{District court's 2016 decision}

Regarding two matrix limitations, the district court interpreted the Federal Circuit in Shire $V$ as "contemplate[ing] that there could be situations where the matrices contain excipients outside of their respective Markush groups." ${ }^{51}$ Consequently, although the granular region and extragranular space did contain excipients that are not within their corresponding Markush groups, the district court considered those excipients as unrelated to the lipophilic characteristics of the granular region or the hydrophilic characteristics of the extragranular space. ${ }^{52}$ Therefore, the district court held that both matrix limitations were met and that its 2013 judgment on infringement remained. ${ }^{53}$

${ }^{38}$ Shire VII, 848 F.3d at 984 (quoting Shire V, 787 F.3d at 1366). The district court followed the Federal Circuit's 2015 decision and held that "(1) the inner lipophilic matrix must exhibit lipophilic characteristics, (2) the outer hydrophilic matrix must exhibit hydrophilic characteristics, and (3) the matrices must be separate." Shire VI, $2016 \mathrm{WL}$ 1258885 , at $* 8$. Such the interpretation was not reversed by the Federal Circuit's 2017 decision. See Shire VII, 848 F.3d at $983-84$.

${ }^{39}$ Shire VII, 848 F.3d at 984 (quoting Shire V, 787 F.3d at 1366).

${ }^{40}$ See Shire VI, 2016 WL 1258885, at *8; see also Shire II, 2013 WL 1912208, at *7. An enteric coating is an "enteric polymer" (e.g., shellac), that is insoluble at low $\mathrm{pH}$ but soluble at a $\mathrm{pH}$ around or below 7. See Rabia Bushra et al., Enteric Coating of Ibuprofen Tablets (200 mg) Using an Aqueous Dispersion System, 46 Brazilian J. Pharmaceutical ScI. 99 (2010), available at http://www.scielo.br/pdf/bjps/v46n1/ 11.pdf (last visited Sept. 19, 2019). A film coating is to coat a thin polymer film onto a tablet, granule or other particle, where the film thickness is usually between 20 and $100 \mu \mathrm{m}$. See John E. Hogan, Film-Coating Materials and Their Properties, in Pharmaceutical Coating Technology 6, 6 (Graham Cole ed., Taylor \& Francis 2002), available at https:// faculty.psau.edu.sa/filedownload/doc-8-pdf-1d87fb03475c5f0 52588cd435b46656d-original.pdf (last visited Sept. 20, 2019). By utilizing a film coating, product appearance or organoleptic properties of a tablet can be improved or facilitating swallowing can be achieved. See Dave Elder, Design, Formulation and Manufacture of Film-Coated Drug Products, European Pharmaceutical Rev., Oct. 25, 2017, https:// www.europeanpharmaceuticalreview.com/article/68115/des ign-formulation-manufacture/ (last visited Sept. 20, 2019).

${ }^{41}$ See Shire VI, 2016 WL 1258885, at $* 8$.

${ }^{42}$ See Shire VI, 2016 WL 1258885, at *9_*10.

${ }^{43}$ See Shire VI, 2016 WL 1258885, at *9; see also Shire II, 2013 WL 1912208, at *13.

${ }^{44}$ See Shire VI, 2016 WL 1258885, at *11-*12; see also Shire II, 2013 WL 1912208, at *6 (“'Granulation' is performed by mixing mesalamine in powder form with a filler (microcrystalline cellulose) and a binding solution of povidone and copovidone in ethanol. That mixture is then put through a device known as a granulator to produce granules.... As the mesalamine granules are dried, the ethanol evaporates, leaving pores in the granules." (citation omitted)).

${ }^{45}$ See Shire VI, 2016 WL 1258885, at *12.

${ }^{46}$ See Shire II, 2013 WL 1912208, at $* 10$.

${ }^{47}$ See Shire VI, 2016 WL 1258885, at $* 14$.

${ }^{48}$ See Shire VII, 848 F.3d at 985; see also Shire II, 2013 WL 1912208 , at *7 ("Watson then blends the mixture of granules and fines with magnesium stearate, sodium starch glycolate, and colloidal silicon dioxide.").

${ }^{49}$ See Shire VII, 848 F.3d at 985.

${ }^{50}$ See Shire VI, 2016 WL 1258885, at *14.

${ }^{51}$ Id.

${ }^{52}$ See id. $* 15$.

${ }^{53}$ See id. at $* 15-* 16$. 
III. ANALYSIS OF SHIRE DEVELOPMENT, LLC V. WATSON PHARMACEUTICALS, INC.

\section{A. Governing law}

As the Shire VII court held, use of "consists of" or "consisting of" in a claim "creates a very strong presumption that that claim element is 'closed' and therefore "exclude[s] any elements, steps, or ingredients not specified in the claim." 54 But, the presumption may be rebutted if "the specification and prosecution history [] unmistakably manifest[s] an alternative meaning[.]" ${ }^{55}$ One example is that "the patentee acts as its own lexicographer." 56

In addition, the Federal Circuit has allowed one rare exception when an accused product shows "aspects unrelated to the [claimed] invention." ${ }^{57}$ For example, in Norian Corp. v. Stryker Corp. ${ }^{58}$ the disputed claim recited "[a] kit for preparing a calcium phosphate mineral, said kit consisting of: at least one calcium source and at least one phosphoric acid source free of uncombined water as dry ingredients; and ... a solution consisting of water and a sodium phosphate, ...."59 The infringer added a spatula into its kit product, while other components of the product were covered by the disputed claim. ${ }^{60}$ But the Federal Circuit there still found infringement because "the spatula has no interaction with the chemicals, and is irrelevant to the invention." 61

\section{B. Infringement analysis}

In Shire VII, the issue was whether the "outer hydrophilic matrix" limitation of claim 1 was met even when magnesium stearate as a lipophilic substance existed in the generic drug's extragranular space. ${ }^{62}$ The district court held that the disputed limitation was satisfied because the magnesium stearate in the extragranular space was unrelated to the claimed invention. ${ }^{63}$ But the Federal Circuit disagreed. ${ }^{64}$ Specifically, the Federal Circuit referred to Norian Corp. and held that the district court erred in "what constitutes a component unrelated to the invention." 65

First, the Federal Circuit highlighted the claimed hydrophilic and lipophilic matrices as what the claimed composition relies on to release mesalazine. ${ }^{66}$ Then, by examining the district court's factual findings, the Federal Circuit concluded that because "the magnesium stearate retains its lipophilic character in the extragranular space[, it] structurally and functionally relates to the invention." 67 Thus, the Federal Circuit held that the presence of the magnesium stearate within the extragranular space violates the "consisting of" requirement in the "outer hydrophilic matrix" limitation. ${ }^{68}$

Second, the Federal Circuit disagreed with the patentee's argument that the magnesium stearate is unrelated to the invention because it serves as a lubricant rather than counts on its lipophilic properties to render the extragranular space lipophilic. ${ }^{69}$ The Federal Circuit emphasized that Norian Corp. "did not restrict 'related' components to only those that advance or are intended to advance a Markush group's allegedly inventive elements." ${ }^{70}$ In addition, the Federal Circuit worried that accepting the patentee's view "would in effect equate the scope of a Markush group's 'consisting of' language with either 'comprising' or 'consisting essentially of' language." 71

Last, the Federal Circuit responded to the patentee's allegation that the specification of the ' 720 Patent taught utilization of magnesium stearate in

${ }^{54}$ Shire VII, 848 F.3d at 984 (quoting Multilayer Stretch Cling Film Holdings, Inc. v. Berry Plastics Corp., 831 F.3d 1350, 1358 (Fed. Cir. 2016)) (alteration in original).

${ }^{55}$ Id. (citing Multilayer Stretch Cling Film Holdings, Inc., 831 F.3d at 1359).

${ }^{56}$ Shire VII, 848 F.3d at 984 (citing Multilayer Stretch Cling Film Holdings, Inc., 831 F.3d at 1359); Conoco, Inc. v. Energy \& Envtl. Int'l, L.C., 460 F.3d 1349, 1359 n.4 (Fed. Cir. 2006)). ${ }^{57}$ Shire VII, 848 F.3d at 984 (quoting Norian Corp. v. Stryker Corp., 363 F.3d 1321, 1321 (Fed. Cir. 2004)).

${ }^{58}$ Norian Corp. v. Stryker Corp., 363 F.3d 1321 (Fed. Cir. 2004).

${ }^{59}$ Norian Corp., 363 F.3d at 1324-25 (emphasis added); see also Shire VII, 848 F.3d at 984-85.

${ }^{60}$ See Norian Corp., 363 F.3d at 1331.

${ }^{61}$ Norian Corp., 363 F.3d at 1332; see also Shire VII, 848 F.3d at 985 .

${ }^{62}$ See Shire VII, 848 F.3d at 985.

${ }^{63}$ See id.

${ }^{64}$ See id.

${ }^{65} \mathrm{Id}$.

${ }^{66}$ See id.

${ }^{67}$ See id. at $985-86$.

${ }^{68}$ See id. at 986.

${ }^{69}$ See id. at 986.

${ }^{70} \mathrm{Id}$.

${ }^{71}$ Shire VII, 848 F.3d at 986 (citations omitted). A claim with a "comprising" phrase is "is inclusive or openended and does not exclude additional, unrecited elements[.]" CIAS, Inc. v. All. Gaming Corp., 504 F.3d 1356, 1360 (Fed. Cir. 2007) (citation omitted); see also Shire VII, 848 F.3d at 986 . A claim with a phrase "consisting essentially of" includes "components not listed in the claim, provided that they do not "materially affect the basic and novel properties of the invention." AK Steel Corp. v. Sollac \& Ugine, 344 F.3d 1234, 1239 (Fed. Cir. 2003) (citations omitted); see also Shire VII, 848 F.3d at 986. 
the outer, hydrophilic matrix of the claimed composition. ${ }^{72}$ The Federal Circuit criticized that the patentee failed to argue the district court's interpretation of "consisting of." 73 Additionally, the Federal Circuit found no intrinsic evidence that can alter the well-established meaning of "consisting of." ${ }^{74}$ Furthermore, the Federal Circuit recalled its previous holding in Multilayer Stretch Cling Film Holdings, Inc. v. Berry Plastics Corp. that "a patent specification's listing of components not listed in a Markush group was insufficient to overcome the presumption created by 'consisting of' claim language[.]"75 Therefore, the Federal Circuit concluded that the patentee still failed to "overcome the exceptionally strong presumption that Markush groups are closed." 76

\section{IMPLICATIONS FOR DESIGN-AROUND OF A MMX-BASED TABLET DRUG}

As the Federal Circuit in Slimfold Manufacturing Company, Inc. v. Kinkead Industries, Inc. observed, "[d]esigning around patents is, in fact, one of the ways in which the patent system works to the advantage of the public in promoting progress in the useful arts, its constitutional purpose." tected invention is what the claims say it is," infringement can be prevented "by avoiding the language of the claims." ${ }^{78}$ Particularly, for a claim with a transitional phrase "consisting of," designing around such claim can be achieved "by adding any step or element not recited in the claim." dition and opens a door for generic drug companies to design around the patented $\mathrm{MMX}^{\circledR}$ technology.

\section{A. '720 Patent-uncovered formulations}

The specification of the ' 720 Patent presents five formulations of inactive excipients as shown in Table $1 .^{80}$ Each formulation is encompassed with a gastro-resistant coating made of cellulose acetophthalate (or polymethacrylates) and a plasticizer. ${ }^{81}$ In addition, according to the approved label of Lialda, the formulation of Lialda tablets which does not match the formulations in Table 1 includes "sodium carboxymethylcellulose, carnauba wax, stearic acid, silica (colloidal hydrated), sodium starch glycolate (type A), talc, magnesium stearate, methacrylic acid copolymer types A and B, triethylcitrate, titanium dioxide, red ferric oxide and polyethyleneglycol 6000."82

Under Shire VII, the ' 720 Patent is not infringed as long as a generic drug uses magnesium stearate in the outer matrix. ${ }^{83}$ Magnesium stearate is commonly used as a lubricant in drug manufacturing to enhance flow- ability of blends or powders. ${ }^{84}$ The specification of the '720 Patent indicates that those five formulations utilize magnesium stearate as a lubricant in the outer matrix as the patentee asserted in Shire VII. ${ }^{85}$ Because the '720 Patent is the listed patent for Lialda, Lialda also includes magnesium stearate as a lubricant in the outer matrix. ${ }^{86}$ Therefore, in addition to the formulation of Watson's generic drug, ${ }^{87}$ those five patent-disclosed formulations and the FDA-approved formulation are outside claim 1 of the ' 720 Patent.

\section{B. Magnesium stearate and its family compounds}

As a lubricant, magnesium stearate (UNII: 70097M 6I30) belongs to a category of metallic salts of fatty acids. ${ }^{88}$ In the same category, there are two other FDA-approved options: calcium stearate (UNII: 776X M7047L) and zinc stearate (UNII: H92E6QA4FV). ${ }^{89}$ A metallic salt of fatty acid has a long, unbranched hydrocarbon chain that expresses a lipophilic or

\footnotetext{
${ }^{72}$ See Shire VII, 848 F.3d at 986. For example, the second example in the specification teaches:

The resulting granules [composed of mesalazine and other excipients] are loaded into a mixer in which $80 \mathrm{~g}$ of hydroxypropyl methylcellulose and $12 \mathrm{~g}$ of sodium starch glycolate are sequentially added. After a first mixing step, $11 \mathrm{~g}$ of silica colloidal and $11 \mathrm{~g}$ of magnesium stearate are added. The final mixture is homogenized, then tableted to a unitary weight of $1144 \mathrm{mg} / \mathrm{tablet}$.
}

U.S. Patent No. 6,773,720 col.4 11.39-44 (emphasis added).

${ }^{73}$ See Shire VII, 848 F.3d at 986.

${ }^{74}$ See id.

${ }^{75}$ Id. (citing Multilayer Stretch Cling Film Holdings, Inc., 831 F.3d at 1359)

${ }^{76} I d$. (citation omitted).

${ }^{77}$ Slimfold Mfg. Co. v. Kinkead Indus., Inc., 932 F.2d 1453, 1457 (Fed. Cir. 1991).

${ }^{78}$ Id.

${ }^{79}$ Immunocept, LLC v. Fulbright \& Jaworski, LLP, 504 F.3d 1281, 1286, 1286 n.4 (Fed. Cir. 2007).

${ }^{80}$ See U.S. Patent No. 6,773,720 col.4 1.10-col.6 1.5.

${ }^{81}$ See U.S. Patent No. 6,773,720 col.4 11.22-25, 45-47, 6567, col.5 11.20-22, 43-45.

${ }^{82}$ FDA, Label of Lialda ${ }^{\mathrm{TM}}$, at 1 (emphasis added), available at https://www.accessdata.fda.gov/drugsatfda_docs/label/ 2009/022000s002lbl.pdf (last visited Sept. 27, 2019).

${ }^{83}$ See supra Part.III.B.

${ }^{84}$ See Jinjiang Li and Yongmei Wu, Lubricants in Pharmaceutical Solid Dosage Forms, 2 LubRICANTs 21, 22, 26-27 (2014), available at https://www.mdpi.com/2075-4442/2/1/ 21/pdf (last visited Sept. 27, 2019).

${ }^{85}$ See Shire VII, 848 F.3d at 986.

${ }^{86}$ See supra Part.I.

${ }^{87}$ See supra Part.III.B.

${ }^{88}$ See $\mathrm{Li}$ and $\mathrm{Wu}$, supra note 84 , at 26-27.

${ }^{89}$ See id. at 27. 
Table 1. Five Formulations Disclosed in the '720 Patent

\begin{tabular}{|c|c|c|}
\hline Example & Inner matrix & Outer matrix \\
\hline 1 & $\begin{array}{l}\text { carnauba wax; } \\
\text { stearic acid. }\end{array}$ & $\begin{array}{l}\text { Carbopol 971P; } \\
\text { hydroxypropyl methylcellulose; } \\
\text { microcrystalline cellulose; } \\
\text { magnesium stearate. }\end{array}$ \\
\hline 2 & $\begin{array}{l}\text { carnauba wax; } \\
\text { stearic acid. }\end{array}$ & $\begin{array}{l}\text { hydroxypropyl methylcellulose; } \\
\text { sodium starch glycolate; } \\
\text { silica colloidal; } \\
\text { magnesium stearate. }\end{array}$ \\
\hline 3 & $\begin{array}{l}\text { beeswax; } \\
\text { palmitic acid. }\end{array}$ & $\begin{array}{l}\text { hydroxypropyl methylcellulose; } \\
\text { microcrystalline cellulose; } \\
\text { sodium starch glycolate; } \\
\text { colloidal silica; } \\
\text { magnesium stearate. }\end{array}$ \\
\hline 4 & $\begin{array}{l}\text { carnauba wax; } \\
\text { stearic acid. }\end{array}$ & $\begin{array}{l}\text { polyacrylamide; } \\
\text { microcrystalline cellulose; } \\
\text { colloidal silica; } \\
\text { hydroxypropyl methylcellulose; } \\
\text { sodium alginate; } \\
\text { calcium carbonate; } \\
\text { microcrystalline cellulose; } \\
\text { magnesium stearate. }\end{array}$ \\
\hline 5 & $\begin{array}{l}\text { carnauba wax; } \\
\text { stearic acid. }\end{array}$ & $\begin{array}{l}\text { hydroxypropyl methylcellulose; } \\
\text { sodium starch glycolate; } \\
\text { sodium carbonate; } \\
\text { magnesium stearate. }\end{array}$ \\
\hline
\end{tabular}

hydrophobic property. ${ }^{90}$ Thus, calcium stearate and zinc stearate could be a potential substitute for magnesium stearate. ${ }^{91}$

\section{Doctrine of equivalents: Unavailable}

Shire VII shows that a generic drug with magnesium stearate in the outer matrix cannot literally infringe the ' 720 Patent. Then, the question is whether the doctrine of equivalents (DOE) applies to such a generic drug. ${ }^{92}$ The answer is no.

Under the DOE, "[e]ven when an accused product does not meet each and every claim element literally, it may nevertheless be found to infringe the claim "if there is "equivalence" between the elements of the accused product or process and the claimed elements of the patented invention." ${ }^{93}$ One way to show equivalency is called the function-way-result test which requires "showing on an element-by-element basis that 'the accused product performs substantially the same function in substantially the same way with substantially the same result as each claim limitation of the patented product[.]" 94 The other way is called "the insubstantial differences test [asking] whether the accused product or process is substantially different from what is patented[.]" 95

The Federal Circuit has clarified that "the drafter's choice of the phrase 'consisting of' does not foreclose infringement under the doctrine of equiv- alents." 96 But, the DOE is barred by prosecution history estoppel (PHE). ${ }^{97}$

One way to trigger PHE is claim amendment in response to office actions. ${ }^{98}$ Narrowing a claim during prosecution creates a presumption of "a general disclaimer of the territory between the original claim and the amended claim." 99 However, such a presumption may be rebutted by showing that (1) the alleged "equivalent may have been unforeseeable at the time of the application"; (2) "the rationale underlying the amendment may bear no more than a tangential relation to the equivalent in question"; or (3) "there may be some other reason suggesting that the patentee could not reasonably be expected to have described the insubstantial substitute in question." 100

In Duramed Pharmaceuticals, Inc. v. Paddock Laboratories, Inc., claim 1 recited a "pharmaceutical composition in a solid, unit dosage form capable of oral administration for the hormonal treatment of perimenopausal, menopausal and post-menopausal disorders in a woman comprising:... wherein said solid unit dosage form is coated with a moisture barrier

${ }^{90}$ See John Blamire, Lipids and Polysaccharides, BIODOTEDU (2003), http://www.brooklyn.cuny.edu/bc/ahp/LAD/ C3a/C3a_LipPol.html (last visited Oct. 2, 2019) ("While the long, hydrocarbon chain of the fatty acid continues to be strongly hydrophobic, ....").

91 "UNII" (Unique Ingredient Identifier) is "a part of the joint United States Pharmacopeia (USP)/FDA Substance Registration System (SRS)" to provide "unique identifiers for substances in drugs, biologics, foods, and devices based on molecular structure and/or descriptive information." See FDA, Inactive Ingredient Search for Approved Drug Products: Frequently Asked Questions-What Is a UNII?, FDA .GOV (May 6, 2019), https://www.fda.gov/drugs/drug-appro vals-and-databases/inactive-ingredient-search-approved-drugproducts-frequently-asked-questions\#WhatUNII (last visited Oct. 1, 2019).

${ }^{92}$ See Ping-Hsun Chen, From the Unforeseeability Exception to Foreseeability Estoppel: The Federal Circuit's Effort to Limit the Doctrine of Equivalents, 25 FED. CIRCUIT B.J. 71, 71-72 (2015) (discussing the background of the doctrine of equivalents as an alternative to literal infringement).

${ }^{93}$ Intendis GMBH v. Glenmark Pharm. Inc., USA, 822 F.3d 1355, 1360 (Fed. Cir. 2016).

${ }^{94}$ Id.

${ }^{95}$ Mylan Institutional LLC v. Aurobindo Pharma Ltd., 857 F.3d 858, 866 (Fed. Cir. 2017).

${ }^{96}$ Vehicular Techs. Corp., 212 F.3d at 1383.

${ }^{97}$ See Chen, supra note 92, at 77-81 (discussing prosecution history estoppel).

${ }^{98}$ See id. at 77-79.

${ }^{99}$ Intendis GMBH, 822 F.3d at 1364 (quoting Festo Corp. v. Shoketsu Kinzoku Kogyo Kabushiki Co., 535 U.S. 722, 740 41 (2002)).

${ }^{100}$ Id. at 1365 (quoting Festo Corp., 535 U.S. at 740-41). 
coating comprising ethylcellulose." ${ }^{101}$ The original version of claim 1 did not recite "comprising ethylcellulose," while dependent claim 7 originally limited "said moisture barrier coating" to ethylcellulose. ${ }^{102}$ Both claims were initially rejected by the examiner. ${ }^{103}$ But later the examiner agreed to approve the application as long as claim 7 was added into claim $1 .^{104}$ As a result, the disputed patent was issued. ${ }^{105}$

The defendant's generic drug included a coating made of "a polyvinyl alcohol ('PVA') MBC, marketed as Opadry AMB." "106 The patentee alleged that the PVA coating was an equivalent to the ethylcellulose limitation, but the Federal Circuit disagreed. ${ }^{107}$ The Federal Circuit opined that the narrow amendment of claim 1 in response to the examiner's rejection created a presumption of PHE. ${ }^{108}$ Additionally, the Federal Circuit found that the patentee failed to present a rebuttal based on unforeseeability, because one prior art had disclosed PVA MBCs as a moisture barrier coating for pharmaceutical tablets, even though such prior art did not choose PVA MBCs as its preference. ${ }^{109}$

Likewise, in Shire VII, original claim 1 of the application for the '720 Patent did not recite those two Markush limitations of current claim $1{ }^{110}$ The Markush group of the "outer hydrophilic matrix" limitation actually existed in original claim $5 .{ }^{111}$ During prosecution, claim 1 was amended to include claim 5's limitation to respond to the examiner's rejection based on obviousness. ${ }^{112}$ Thus, the "outer hydrophilic matrix" limitation is subject to PHE.

Additionally, use of magnesium stearate, calcium stearate, or zinc stearate as an excipient or lubricant in pharmaceutical compositions had existed before the filing date (December 13, 2001) of the '720 Patent. For example, U.S. Patent Application No. 20010007863 (published on July 12, 2001) teaches pharmaceutical formulations utilizing magnesium stearate or calcium stearate as a lubricant during the tablet manufacturing process. ${ }^{113}$ Another example is U.S. Patent Application No. 2001002 2973 (published on September 20, 2001) that shows zinc stearate as a potential pharmaceutical excipient. ${ }^{114}$

Therefore, when a generic version of Lialda includes magnesium stearate, calcium stearate, or zinc stearate in the extragranular space, it is unlikely to argue that the extragranular space was an unforeseeable equivalent. The owner of the ' 720 Patent may not assert infringement under the DOE.

\section{CONCLUSION}

Lialda implements the MMX technology which features lipophilic and hydrophilic matrices in a tablet.
Claim 1 of the ' 720 Patent, the only one listed patent in the Orange Book for Lialda, recites lipophilic and hydrophilic matrices. However, claim 1 adopts a Markush style to describe both matrices. Specifically, the hydrophilic matrix limitation excludes any unlisted materials, either hydrophilic or lipophilic. However, Watson's generic drug embedded magnesium stearate, a lipophilic substance, in the extragranular space (considered as equivalent to the hydrophilic matrix limitation). As a result, the Federal Circuit in Shire VII found that Watson's generic drug was not covered by claim 1 .

After Shire VII, a generic drug of Lialda is free from the ' 720 Patent as long as magnesium stearate exists in the extragranular space of such generic drug. Calcium stearate and zinc stearate could be a substitute for magnesium stearate, because these three are metallic salts of fatty acids expressing a lipophilic property. Finally, these three stearates had existed as a lubricant or excipient for pharmaceutical compositions before the filing date of the ' 720 Patent, which saves corresponding generic drugs from infringing the ' 720 Patent under the DOE.

\section{ACKNOWLEDGMENT}

This article is associated with a research project financially supported by the Ministry of Science and Technology of the Taiwan Government (MOST 1082320-B-004-001-).

${ }^{101}$ Duramed Pharm., Inc. v. Paddock Labs., Inc., 644 F.3d 1376, 1378 (Fed. Cir. 2011) (emphasis in original).

${ }^{102}$ See id.

${ }^{103}$ See id.

${ }^{104}$ See id.

${ }^{105}$ See id.

${ }^{106}$ Id.

${ }^{107}$ See id. at $1380-81$.

${ }^{108} \mathrm{See}$ id. at 1380.

${ }^{109}$ See id. at $1380-82$.

${ }^{110}$ See Initial Application Document (filed on Dec. 13, 2001) for U.S. Patent No. 6,773,720, at 11, archived at https:// drive.google.com/file/d/1D3LdoDsItKmavWdRCmZvCW_9 XRYSRElI/view?usp=sharing (last visited Oct. 2, 2019).

${ }^{111}$ See id. at 11.

${ }^{112} \mathrm{See}$ Amendment After Final Rejection (filed on Oct. 9, 2003) for U.S. Patent No. 6,773,720, at 2, 5, archived at https://drive.google.com/file/d/1S5e-TytWSmS2JmAMqf3T3 z6aHTjrDAoT/view?usp=sharing (last visited Oct. 2, 2019).

${ }^{113}$ See U.S. Patent Application No. 20010007863, ๆศ 0050, 0085-0089.

${ }^{114}$ See U.S. Patent Application No. 20010022973, 0072. 